\title{
Effects of settlement and post-settlement mortality on the distribution of the ascidian Trididemnum opacum
}

\author{
Michael J. Keough* \& Barbara J. Downes \\ Department of Biological Science, Florida State University, Tallahassee, Florida 32306, USA
}

\begin{abstract}
At Isthmus Reef, Santa Catalina Island, California, colonies of the colonial ascidian Trididemnum opacum occur disproportionately in cracks and crevices on rock surfaces. Small colonies are found in the open, but large colonies occur only in crevices. Transplantation of established colonies into unprotected open habitats showed that they are preyed upon intensively, probably by tish and urchins (up to $19 \%$ mortality $\mathrm{d}^{-1}$ and $80 \% \mathrm{mo}^{-1}$ ), with colonies of all sizes being eaten. Recruitment was primarily into pits in experimental substrata. A caging study of recruitment patterns suggested that the recruitment pattern results from disproportionate but not exclusive settlement of larvae into depressions, followed by differential mortality of colonies in the open during the first month after settlement. Sampling in 1985 suggested that changes during El Niño years of 1982-3 may have resulted in altered abundance and size-distributions of $T$. opacum: Isthmus Reef lost its canopy of Macrocystis pyrifera; the abundance of urchins increased by almost an order of magnitude. $T$ opacum colonies became an order of magnitude less abundant in unprotected habitats and showed a shift towards smaller colony sizes in all habitats.
\end{abstract}

\section{INTRODUCTION}

The influence of settlement on the abundance and spatial pattern of benthic organisms is a source of ongoing controversy (see reviews by Paine 1984 . Underwood \& Denley 1984). For most species, it is not known how much of the spatial distribution or abundance of adults can be ascribed respectively to settlement, post-settlement mortality early in life, and processes involving adults. Recently, there have been attempts to reconcile different views of processes affecting adult population size by constructing either mathematical (Roughgarden et al. 1985) or conceptual (Connell 1985) models that predict variation in the relative importance of settlement and post-settlement processes as a function of settlement density. The influence of settlement on the spatial pattern of adult populations is less well known, and there remains a need for empirical studies that examine many stages of an organism's life history. The answers to these questions are made more elusive because in the past,

-Present address: Dept. of Zoology, University of Melbourne, Parkville, Victoria 3052, Australia recruitment (i.e. settlement + post-settlement mortality) has often been measured in lieu of settlement, but it is not clear that the 2 quantities are well correlated (Keough \& Downes 1982, Connell 1985, Keough 1986).

There are exceptions to this, including barnacles (e.g. Connell 1961, Grosberg 1982, Wethey 1985), ascidians (Bak et al. 1981, Goodbody 1963), and bryozoans (Keough 1986). Some of the most detailed demographic studies have focussed on ascidians of the family Didemnidae, mostly in tropical habitats in the Caribbean (Tridemnum solidum: Bak et al. 1981, van Duyl et al. 1981) and on the Great Barrier Reef (Didemnum molle: Olson 1984, 1985). There exist few comparable data from temperate habitats.

Here we present data from experiments designed to measure the contributions of post-settlement juvenile and adult mortality to the spatial distribution of colonies of the temperate didemnid ascidian Trididemnum opacum at Santa Catalina Island in southern California. Combined with field observations, the experiments allow some inferences to be made about settlement behaviour. These experiments covered a short period, but after the completion of the experiments, there were 2 yr of El Niño conditions, which 
resulted in the loss of overstory kelp Macrocystis pyrifera from large areas (Dayton \& Tegner 1984), including parts of Santa Catalina Island. The densities of some predatory fishes also changed (Cowan 1985). At Isthmus reef, urchins appeared more abundant than before El Niño, and while sheephead Semicossyphus pulcher recruitment appeared to have been high, embiotocids had almost completely vanished from the reef (R. Schmitt pers. comm.). To place our short term results into a longer term context, we resampled $T$. opacum populations in 1985 at Isthmus Reef, which underwent major changes, and at a nearby site that did not appear to have been affected greatly by El Niño. We expected to find that the $T$. opacum population at Isthmus Reef in 1985 was different from that in 1982, but that the population at the nearby site resembled the 1982 Isthmus Reef colonies.

\section{METHODS}

Most work was done at Isthmus Reef, an emergent basaltic rock near the Catalina Marine Science Center on Santa Catalina Island $\left(33^{\circ} 27^{\prime} N, 118^{\circ} 29^{\prime} \mathrm{W}\right)$. Our main study site in 1981 and 1982 was a series of shaded vertical rock walls to the north-east of the emergent part of the reef at $10 \mathrm{~m}$ depth, beneath a canopy of Giant Kelp Macrocystis pyrifera. Wave action and currents here are slight. The rock surfaces have fissures and cracks (usually $>1.5 \mathrm{~cm}$ deep) that make up approximately $5 \%$ of the surface area. A variety of encrusting and arborescent sessile organisms are attached to the rock walls. Encrusting algae, Trididemnum opacum, and encrusting and arborescent bryozoans are the most abundant taxa. In 1985 the Isthmus Reef site had lost its $M$. pyrifera canopy, and we also collected data from 'Intake Pipes', a similar site $200 \mathrm{~m}$ from the intakes of the Catalina Marine Science Center seawater system. Intake Pipes retained an $M$. pyrifera canopy through El Niño.

The encrusting organisms are browsed over by a variety of large predators. Fish are common, and field observations suggested that Embiotica jacksoni juveniles account for the most bites $\mathrm{m}^{-2}$ (M. J. Keough \& B. J. Downes unpubl. obs.), followed by Halichoeres semicinctus and Hypsypops rubicundus. The urchin Centrostephanus coronatus and the mollusks Astraea spp. and Diodora aspera are the most common invertebrates, although only $C$. coronatus was abundant, and then only at Isthmus Reef in 1985. Sea stars were almost totally absent, and small potential predators (nudibranchs, pycnogonids, etc.) were seldom found, despite extensive searches.

The distribution and abundance of Trididemnum opacum on natural surfaces were measured using a series of $15 \mathrm{~m} \times 1 \mathrm{~m}$ transects positioned randomly through the Isthmus Reef site in July 1982, and a series of randomly placed $0.25 \mathrm{~m}^{2}$ quadrats at both Isthmus Reef and Intake Pipes during July and August 1985. We located each $T$. opacum colony and classified it as living in 1 of 3 habitats: in the open (unprotected); in a crevice $(<1.5 \mathrm{~cm}$ wide); or beneath a canopy of large, fleshy algae or zoanthids. The latter 2 habitats were considered to provide varying degrees of protection against fish and urchins. We also measured the size of each colony. Small colonies are approximately circular; we measured their diameter. Larger colonies become progressively less symmetrical, and we measured up to 5 diameters (the number of diameters increasing with a subjective assessment of asymmetry) for each colony, and used the geometric mean as the diameter. Bak et al. (1981) showed that such measurements provide an accurate estimate of colony area.

The distribution of recruits in protected and unprotected habitats was estimated using unglazed clay tiles similar in both colour and texture to naturally-occurring rock surfaces. Each $150 \mathrm{~mm} \times 150 \mathrm{~mm}$ tile had 20 randomly positioned pits $15 \mathrm{~mm}$ in diameter, $5 \mathrm{~mm}$ deep) drilled into the surface. The pits occupied $8 \%$ of the total surface of each tile, or $2 \%$ of the crosssectional area. Five to 10 tiles were submerged for approximately $1 \mathrm{mo}$ in each of September, October, November, and December of 1981 at 4 permanently marked locations within the Isthmus Reef study area. In November and December, half of the tiles were enclosed by plastic-coated wire cages $(65 \mathrm{~mm} \times$ $60 \mathrm{~mm}$ mesh, 5 to $7 \mathrm{~cm}$ off the surface of the tile), to exclude fish and urchins. All tiles in September and October were uncaged.

To estimate adult mortality, we suspended 10 tiles with their experimental surfaces facing and $1 \mathrm{~cm}$ or less from the rock wall, so that encrusting organisms could grow free from predators. After approximately 3 mo, some Trididemnum opacum colonies had reached a diameter of $24 \mathrm{~mm}$. There were at that time very few colonies on the exposed (outward facing) surfaces of the tiles, although we observed recruitment on those surfaces throughout the period. The tiles were then turned around, and all established $T$. opacum colonies on protected surfaces were mapped. The tiles were then arranged into 2 groups of 5 tiles, with the groups at the same depth and separated by $3 \mathrm{~m}$ horizontally. The 2 groups are referred to as sites, allowing us to document one scale of spatial variation in mortality. There were no obvious differences between the 2 sites. At each site, 2 randomly selected tiles were caged, again using the $65 \mathrm{~mm} \times 60 \mathrm{~mm}$ mesh cages. The tiles were left for $3 \mathrm{~d}$, after which time we returned and relocated surviving colonies. We resurveyed the caged and uncaged tiles 1 mo later. 
In 1985 we allowed Trididemnum opacum colonies to establish in the same manner at Isthmus Reef, and then exposed 5 tiles each with approximately $30 \mathrm{col}-$ onies. None were caged, and the manipulations were done simply to provide estimates of mortality on exposed surfaces comparable to those in 1982

\section{RESULTS}

Size-frequency distributions of colonies in the 3 habitat categories (Fig. 1) were compared between the 3 samples (Isthmus Reef 1982 and 1985 and Intake Pipes 1985) using log-linear models. The size-frequency distributions were highly heterogeneous
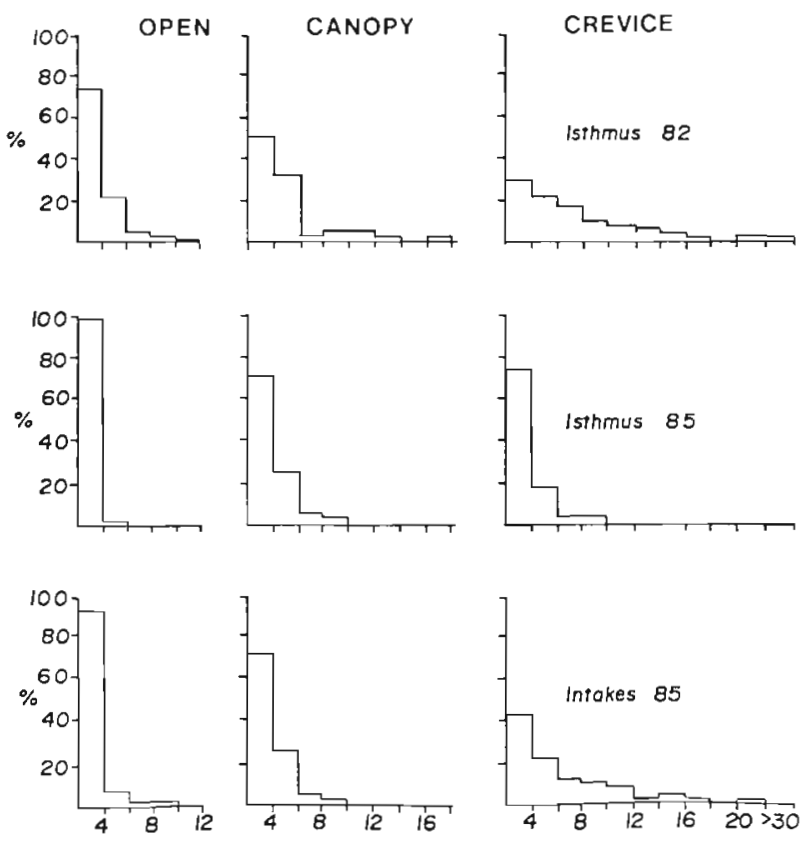

COLONY DIAMETER $(\mathrm{mm})$

Fig 1. Trididemnum opacum. Size-frequency distributions of all colonies in transects and random quadrats in 3 samples (Isthmus Reef 1982 and 1985, Intake Pipes 1985), and in 3 natural habitats (open, crevice, canopy). Sample sizes are as follows. Isthmus Reef 1982: Open 455, Canopy 162, Crevice 397; Isthmus Reef 1985: Open 39, Canopy 318, Crevice 229; Intake Pipes 1985: Open 302, Canopy 260, Crevice 108

(Table 1). In all samples, larger colonies occurred in protected habitats; no colonies $>14 \mathrm{~mm}$ in diameter were found in the open, and more than $95 \%$ of colonies were $<6 \mathrm{~mm}$ in diameter (Fig. 1). Colonies were slightly larger in canopy habitats, but the largest colonies were in crevices inaccessible to fish and urchins. Small colonies (diameter $<6 \mathrm{~mm}$ ) were common in all 3 habitats. The sample sizes were so large that we were able to detect very small changes in size distributions, and Bishop et al. (1975) have suggested a crude rela- tive guide $(\mathrm{G} / \mathrm{n})$ for distinguishing 'important' effects from significant results that are the result simply of sample size. Examination of these statistics shows that for comparisons between habitats, the difference was greatest between crevice and open habitats in all 3 samples (Table 1). Similarly, for the comparisons between samples, $\mathrm{G} / \mathrm{n}$ values were smallest for colonies in the open and largest for those for colonies in crevices.

The second important difference was the change at Isthmus Reef between 1982 and 1985. Colonies in all habitats were smaller in 1985 . The changes were least for colonies in the open. The size-frequency distribution of colonies in crevices at Intake Pipes was no different from that at Isthmus Reef in 1982, but colonies in both populations were much larger than at Isthmus Reef in 1985.

The densities of Trididemnum opacum also decreased in some habitats. The transects used in 1982 to measure size-frequency distributions can give an estimate only of the mean density; the quadrats used in 1985 give appropriate estimates of the variance. In the open, the density of colonies at Isthmus Reef was much lower in 1985 than in 1982 (t-test, assuming that 1982 value represented the true population density, $t=160$, $\mathrm{df}=47, \mathrm{P} \ll 0.001$ ), and while the mean density at Intake Pipes was higher than for either Isthmus Reef sample (t-test for 1985 samples, $t=9.1, \mathrm{df}=67$. $\mathrm{P}<0.001$; no statistical comparison between 1985 samples and 1982 sample), the variance was very large (Table 2). Under canopies, the means of the 3 samples differed, but variances were very large, possible reflecting simply algal patchiness. The mean densities of colonies in crevices in 1985 samples were not significantly different $(t=0.11$, df $=67, P>0.3)$, and were close to the 1982 sample value.

Colonies recruited disproportionately into pits on experimental substrata (Table 3); the proportion of recruits in pits exceeded both the surface area of the pits relative to the tile area $(8 \%)$ and the cross-sectional area of the pits ( $2 \%$ ). After 1 mo, only $8 \%$ of recruits were found on exposed surfaces. Distributions of the ascidian on caged and uncaged substrata differed slightly, with a greater proportion of recruits being found on flat surfaces of caged substrata than corresponding surfaces of uncaged substrata (Table 3 ).

By the start of the predation experiment, the colonies that had been growing on the protected sides of tiles did not differ significantly in size-frequency distribution from the colonies in crevices $(\mathrm{G}=4.33, \mathrm{df}=7$, $\mathrm{P}>0.10)$. After the tiles were turned around, established colonies died quickly (56\% in 3 d) at 1 of the 2 sites, and even at the other site $13 \%$ of the colonies died in the first $3 \mathrm{~d}$ (Table 4 ). At both sites, a substantial proportion of colonies disappeared within $1 \mathrm{mo}$, 
Table 1. Trididemnum opacum. Contingency table analyses of size-trequency distributions of colonies in 3 habitats in 3 samples. All statistics are goodness-of-fit to the appropriate log-linear model. For 3 -factor comparison, G-statistic is a test of the independence of all 3 factors. Williams correction for continuity (Bishop et al. 1975) was applied to all significant G-statistics. ns: $\mathrm{P}>0.05 ; \cdot 0.05>\mathrm{P}>0.01 ; \cdots 0.01>\mathrm{P}>0.001 ; \cdots \mathrm{P}<0.001$

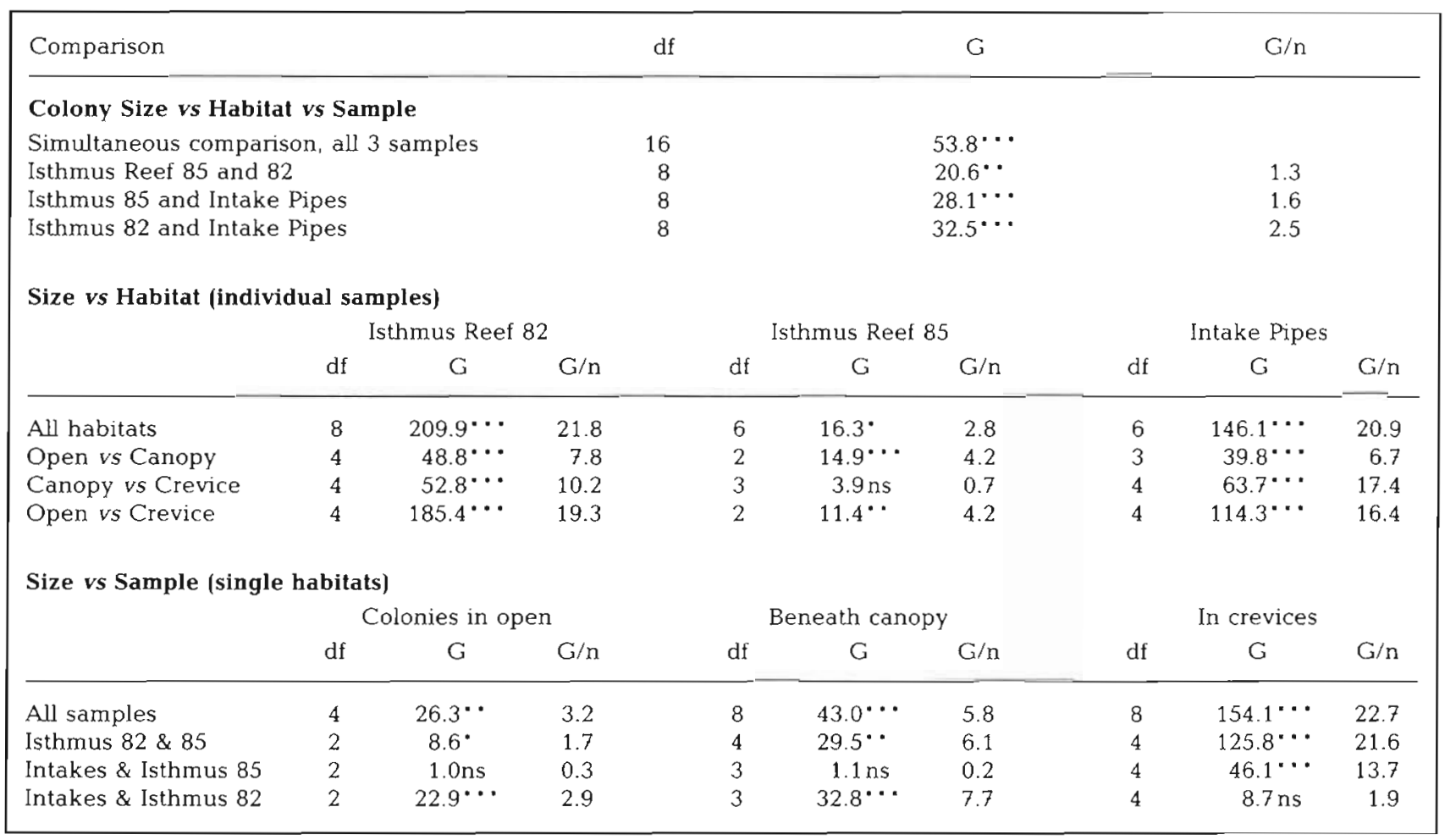

Table 2. Trididemnum opacum. Densities (colonies $\mathrm{m}^{-2}$ ) in 3 microhabitats at Isthmus Reef in 1982 and 1985 and Intake Pipes in 1985. The 1982 samples was based on two $15 \times 1 \mathrm{~m}$ transects. For the other samples, mean and standard deviation of the mean are shown

\begin{tabular}{|clcccc|}
\hline \multicolumn{2}{c}{ Sample } & & Open & Canopy & Crevice \\
\cline { 5 - 6 } Isthmus Reef 1982 & $\overline{\mathrm{X}}$ & 15.1 & & 11.1 & 17.7 \\
& $\mathrm{SD}$ & - & & - \\
Isthmus Reef 1985 & $\overline{\mathrm{X}}$ & 1.1 & 26.2 & 21.2 \\
$(\mathrm{n}=49)$ & $\mathrm{SD}$ & 0.6 & 8.4 & 5.9 \\
Intake Pipes 1985 & $\overline{\mathrm{X}}$ & 65.8 & 52.0 & 21.4 \\
$(\mathrm{n}=20)$ & $\mathrm{SD}$ & 50.4 & 37.6 & 10.1 \\
& & & & \\
\hline
\end{tabular}

while there was no mortality over $3 \mathrm{~d}$ on caged substrata, and only $5 \%$ over 1 mo. Fish (Halichoeres semicinctus and Embiotica jacksoni) were seen eating colonies during mapping.

In addition to the complete removal of colonies, large colonies on open surfaces were damaged extensively (Table 4). After $1 \mathrm{mo}$, the only surviving colonies were $<10 \mathrm{~mm}$ in diameter, and even over $3 \mathrm{~d}, 6$ of 8
Table 3. Trididemnum opacum. Distribution of recruits in pits and on exposed surfaces of caged and uncaged panels exposed during Nov and Dec 1981 and on uncaged panels exposed during Sep and Oct 1981. Data within caged and uncaged treatments were not significantly heterogeneous $(G-$ test, $\mathrm{df}=3$ for uncaged, $\mathrm{G}=2.3$; for caged, Fisher's exact test, $\mathrm{p}=0.4$ ) and were pooled across time periods. Distributions of recruits in pits and on exposed surfaces were compared to $2: 98$ and $8: 92$ ratios, and caged distributions were compared to uncaged ones. All tests were log likelihood ratio tests, with $\mathrm{df}=1$, or binomial exact probabilities

\begin{tabular}{|c|c|c|c|c|}
\hline & & \multicolumn{2}{|c|}{$\begin{array}{l}\text { No. of recruits } \\
\text { in pits }\end{array}$} & \multirow{2}{*}{$\frac{\begin{array}{c}\text { No. of recruits } \\
\text { on exposed } \\
\text { surfaces }\end{array}}{6}$} \\
\hline Caged tiles & $(\mathrm{n}=11)$ & 11 & & \\
\hline Uncaged tile & $s \quad(n=18)$ & $49^{\circ}$ & & 4 \\
\hline $2: 98$ ratio & $\begin{array}{l}\text { Caged } \\
\text { Uncaged }\end{array}$ & \multicolumn{3}{|c|}{$\begin{array}{l}p<0.001 \\
p<0.001\end{array}$} \\
\hline $8: 92$ ratio & $\begin{array}{l}\text { Caged } \\
\text { Uncaged }\end{array}$ & \multicolumn{3}{|c|}{$\begin{array}{l}p<0.001 \\
p<0.001\end{array}$} \\
\hline $\begin{array}{l}\text { Caged vs Un } \\
\text { - Sep-Oct: } 3\end{array}$ & $\begin{array}{l}\text { icaged } \\
7 \text {; Nov-Dec: }\end{array}$ & $\begin{array}{l}G=5.21 \\
12\end{array}$ & $p<0$ & .025 \\
\hline
\end{tabular}


Table 4. Trididemnum opacum. Short-term mortality of colonies on protected (caged) and exposed substrata and distribution of mortality and colony damage with size. Except where indicated, all numbers are percent mortality, with numbers of colonies in parentheses. Mortalities were compared by $2 \times 2$ contingency tables and log-likelihood ratio test. Significance values are indicated on the table; symbols between columns for the 2 sites show comparisons between sites, while symbols alongside the column for protected tiles show comparisons between protected and all exposed tiles. ns: $\mathrm{p}>0.05 ; \cdot 0.05>p>0.01 ; \cdots p<0.001$; - no test was done

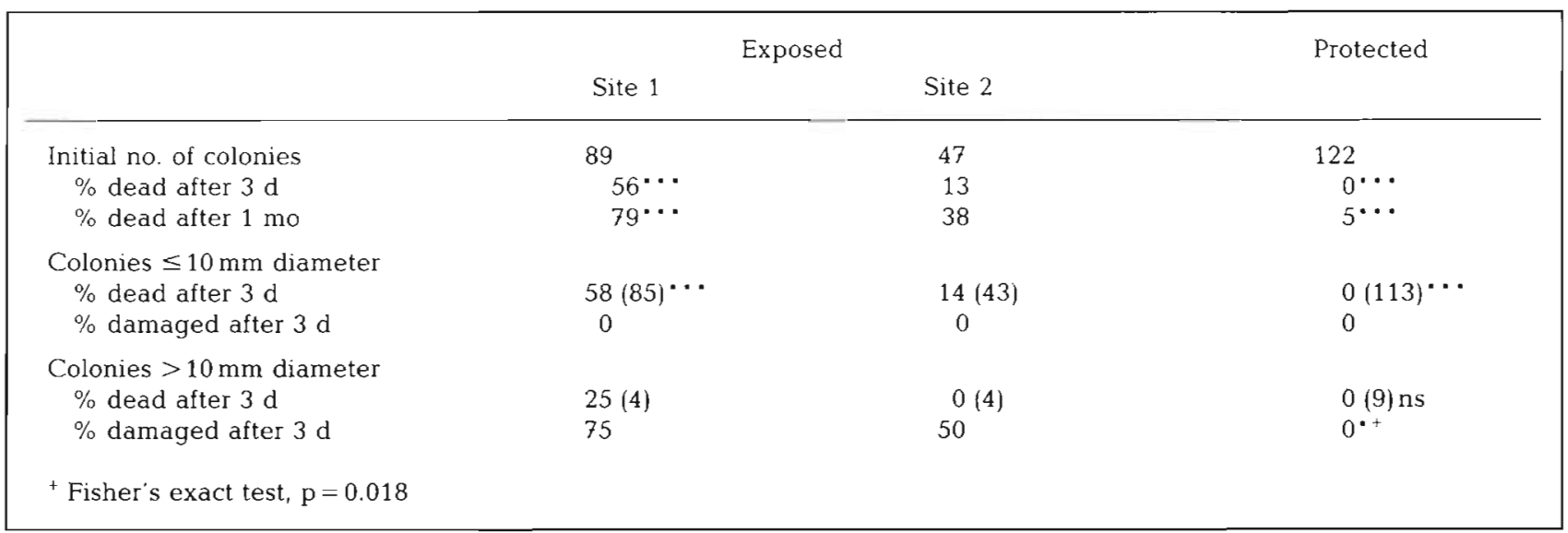

colonies larger than $10 \mathrm{~mm}$ were damaged or killed. In the 1985 experiment, all colonies disappeared from the tiles within $1 \mathrm{wk}$ of exposure to predators.

Colonies of the arborescent bryozoan Scrupocellaria bertholetti were followed at the same time and suffered even greater mortality over the first $3 \mathrm{~d}(90 \%$ of 20 colonies at Site 1 and $72 \%$ of 18 at Site 2 ), although mortality did not differ significantly between the 2 sites $(2 \times 2$ contingency table, Fisher's exact test, $\mathrm{P}=0.83)$.

\section{DISCUSSION}

Trididemnum opacum colonies show 2 striking distributional patterns. They are distributed heterogeneously among habitats, and the population at Isthmus Reef in 1985 was both distributed differently from and smaller than the population at the same site in 1982 . Our experiments allow us to suggest explanations for the distribution of colonies among different habitats, and the measurements made at Isthmus Reef in 1982 and at both sites in 1985 allow us to draw some inferences about processes that influence $T$. opacum colonies on larger temporal and spatial scales.

Trididemnum opacum colonies show a shift in sizefrequency distribution between habitats: unprotected habitats are characterised by very small colonies, whereas larger colonies occur almost exclusively in crevices, and to a lesser degree beneath algal canopies. Our caging experiment shows that unprotected colonies in the open suffer very high mortalities in very short time spans. There appears to be no refuge in size; even large colonies survive poorly in the open, and those colonies surviving for longer than 1 mo were small. Our experiments included the whole size range of natural colonies. For many colonial species, including tunicates, reproductive output increases with colony size (Nakauchi 1982). Thus, a larva settling in a crevice would have a higher expected (mean) fitness than one settling beneath an algal canopy, which in turn would have higher fitness than a larva settling in the open.

The recruitment experiments demonstrate that recruits occur disproportionately in protected habitats. The significant difference in spatial distributions between caged and uncaged substrata suggest that postsettlement mortality of colonies on flat, unprotected surfaces from large predators accounts for part of the recruitment pattern. The small magnitude of the difference suggests that this source of mortality is small, however, since even on caged substrata most recruits occur in pits. This latter result suggests that many, but not all, Trididemnum opacum larvae settle into small crevices and pits. The recruitment pattern might result of course from disproportionate mortality on flat surfaces from either predators small enough to enter our cages freely, or from physical factors. In the absence of direct observations, we are unable to reject completely these suggestions. Our failure to find many small predators suggests that they are unimportant, however. Siltation and algal growth have been shown to kill juvenile solitary ascidians (Young \& Chia 1984). In our experiments the vertical orientation of the substrata prevented sediment accumulation, and there was very little algal growth over the duration of the experiments. It is also possible that the recruitment patterns reflect the sensitivity of the ascidians to ultraviolet 
radiation, as has been shown for Didemnum molle (Olson 1984), but the shading provided by the Macrocystis pyrifera canopy in 1981-2 makes this an unlikely explanation, as does the high survivorship of caged colonies. (The large mesh sizes resulted in minimal shading.) We consider that disproportionate settlement, accentuated by the disproportionate death of colonies in the open within a month of settling, most likely accounts for the recruitment pattern. The low recruitment rates seen here and for other colonial sessile animals (Keough 1983, 1986) make it difficult to make the direct observations of settlement that have been made for barnacles (Connell 1961, 1985), and for many colonial species, circumstantial evidence of settlement patterns may be the only possibility.

Preferential recruitment into crevices on bivalve shells has been suggested previously for Tridemnum opacum by Vance (1978), although he had no data on settlement. Vance interpreted the recruitment pattern as a response to grazing by the urchin Centrostephanus coronatus. However, at the time of our experiments, $C$. coronatus was much less common at Isthmus Reef than at his study site, Bird Rock, while fish were commoner, and were frequently seen browsing on the biota of rock surfaces (Keough \& B. J. Downes unpubl. obs.).

The arborescent bryozoan Scrupocellaria bertholetti produced similar experimental results to Trididemnum opacum: colonies in the open disappeared very quickly, and we have shown previously that $S$. bertholetti recruits even more disproportionately into pits, although the spatial pattern is unaffected by the presence of large predators (Keough \& Downes 1982).

The second major pattern is the change in distribution and abundance of Trididemnum opacum at Isthmus Reef. The changes since El Niño have been dramatic; the kelp canopy disappeared completely, and Centrostephanus coronatus became abundant at densities of around 5 ind $\mathrm{m}^{-2}$ (Keough unpubl. obs.), whereas they were previously much less than 1 ind $\mathrm{m}^{-2}$. Our impression is that the abundance of understory algae has also been altered. It is difficult to ascribe any changes in $T$. opacum to El Niño unequivocally; we had no way of predicting that it would occur, let alone which sites would be affected. We chose Intake Pipes as a 1985 sampling site because it superficially resembled Isthmus Reef in 1982. The kelp canopy was still present, and urchin abundances were low. We thus have $3 / 4$ of an orthogonal design, missing 1982 Intake Pipes samples. The change in size distribution of the $T$. opacum population at Isthmus Reef is marked, but the population at Intake Pipes was also composed of smaller individuals than that at Isthmus Reef in 1982. The latter difference was much smaller than between the Isthmus Reef samples, however. The change in abundance of $T$. opacum colonies in the open is much more striking: the density fell from around 20 to 1 ind $\mathrm{m}^{-2}$. There was an increase in $T$. opacum beneath understory algae, no changes in abundance in crevices, and colonies were still common in the open at Intake Pipes.

With these data, we are unable to explain the change in Trididemnum opacum populations. The loss of a kelp canopy increased light levels greatly, and urchins became abundant, increasing grazing pressure. The changes that we see are consistent with both sensitivity to ultraviolet radiation and grazing. We believe however, that the primary cause is grazing. All of the colonies that we exposed in 1985 were removed within 1 wk. During the course of other field work at this time we examined the tiles at frequent intervals and found frequent urchin grazing scars on the tiles.

The large-scale effects of El Niño, such as those on fish recruitment (Cowan 1985, Sinclair 1985), eastern Pacific corals (Glynn 1984) and kelp (Dayton \& Tegner 1984) have received much attention. Our data suggest that there may have been dramatic changes in some benthic invertebrate populations during the El Niño years. Dayton \& Tegner (1984) reported unsuccessful recruitment of Macrocystis pyrifera following El Niño, despite successful settlement. They attributed this to the effects of established understory algae on small $M$. pyrifera, and suggested that return of $M$. pyrifera to these areas may not occur rapidly. There has been no successful recruitment of $M$. pyrifera at Isthmus Reef since El Niño, although small plants are common at Intake Pipes. The longevity of the urchin, and the failure of the kelp to recruit thus far following El Niño, suggest that whatever the cause of the change in the Trididemnum opacum population, it is likely to be a persistent one. This is made more likely by the limited dispersal of most didemnid ascidian larvae (van Duyl et al. 1981, Olson 1985), and the relatively isolated nature of Isthmus Reef, which is $>500 \mathrm{~m}$ from any other shallow reef area. Such a phenomenon has been shown to occur on an even smaller spatial scale for an arborescent bryozoan, Bugula neritina, which also shows restricted larval dispersal. Small-scale patchiness of populations reflects past extinctions, and the absence of colonies from particular sites reflects a failure to disperse and recolonize, rather than unsuitability of the sites (Keough \& Chernoff 1986).

The changes at Isthmus Reef, and the differences between Isthmus Reef and Intake Pipes in 1985, are as large as either the differences in mortality rates between sites or the differences between habitats. They are, however, less predictable - the probable escape of Intake Pipes from effects of the El Niño years was difficult to predict, and the patchiness thus generated is on a scale much larger than the likely dispersive 
ability of Trididemnum opacum. Thus, the predictable, within-generation variation in survival between habitats is overlain by unpredictable, but demographically important events that occur on the scale of whole populations, and on a time scale that spans many generations.

Acknowledgements. We thank A. Butler, J. Farr, R. Olson, D. Strong, and C. Young for commenting on the manuscript, and Drs. R. Given and A. Muscat for permission to use facilities at CMSC. J. Schmidt, S. Swarbrick and R . Varon provided diving assistance. Financial support was provided by NSF grant OCE-8400404 (to M.J.K.), an NSF grant to J. H. Connell, and the Academic Senate, University of California, Santa Barbara. We also gratefully acknowledge support provided by the NOAA National Undersea Research Program's Tether Diving Program. This is contribution No. 107 from the Catalina Marine Science Center.

\section{LITERATURE CITED}

Bak, R. P., Sybesma, J., Duyl, F. C. van (1981). The ecology of the tropical compound ascidian Trididemnum solidum. II. Abundance, growth and survival. Mar. Ecol. Prog. Ser 6: $43-52$

Bishop, Y. M. M., Feinberg, S. E., Holland, P. W. (1975). Discrete multi-variate analysis. MIT Press, Cambridge, Massachusetts

Connell, J. H. (1961). Effects of competition, predation by Thais lapillus, and other factors on natural populations of the barnacle Balanus balanoides. Ecol. Monogr. 31: 61-104

Connell, J. H. (1985). The consequences of variation in initial settlement vs post-settlement mortality in rocky intertidal communities. J. exp. mar. Biol. Ecol. 93: 11-46

Cowan, R. K. (1985). Large scale pattern of recruitment by the labrid, Semicossyphus pulcher: causes and implications. J. mar. Res. 43: 719-742

Dayton, P. K., Tegner, M. F. (1984). Catastrophic storms, El Niño and patch stability in a southern Californian kelp forest. Science 224: 283-285

Duyl, F. C. van, Bak, R. P. M., Sybesma, J. (1981). The ecology of the tropical compound ascidian Trididemnum solidum. I. Reproductive strategy and larval behaviour. Mar. Ecol. Prog. Ser. 6: 35-42

Goodbody, I. M. (1963). The biology of Ascidia nigra (Savigny). II. The development and survival of young ascidians. Biol. Bull. mar biol. Lab., Woods Hole 124: $31-44$
Glynn, P. W. (1984). Widespread coral mortality and the 1982-3 El Nin̄o warming event. Environ. Conserv. 11: $133-146$

Grosberg, R. K. (1982). Intertidal zonation of barnacles: the influence of planktonic zonation of larvae on vertical distribution of adults. Ecology 63: 894-899

Keough, M. J. (1983). Patterns of recruitment of sessile invertebrates in two subtidal habitats. J. exp. mar. Biol. Ecol. 66: 213-245

Keough, M. J. (1986). The distribution of the bryozoan Bugula neritina on seagrass blades: settlement, growth and mortality. Ecology 67: 846-857

Keough, M. J., Chernoff, H. (1986). Dispersal and population variation in the bryozoan Bugula neritina. Ecology (in press)

Keough, M. J., Downes, B. J. (1982). Recruitment of marine invertebrates: the role of active larval choices and early mortality. Oecologia (Berl.) 54: 348-352

Nakauchi, M. (1982). Asexual development of ascidians: its biological significance, diversity, and morphogenesis. Am. Zool. 22: 753-763

Olson, R. R. (1984M). Ascidian-Prochloron symbiosis: the role of larval photoadaptation in midday larval release and settlement. Biol. Bull. mar. biol. Lab., Woods Hole 165: 221-240

Olson, R. R. (1985). The consequences of short-distance larval dispersal in a sessile marine invertebrate. Ecology 66 : 30-39

Paine, R. T (1984). Ecological determinism in the competition for space. Ecology 65: 1339-1348

Roughgarden, J., Iwasa, Baxter, C. (1985). Demographic theory for an open marine population with space-limited recruitment. Ecology 66: 54-67

Sinclair, M. (1985). El Niño events and variability in a Pacific mackerel (Scomber japonicus) survival index: support for Hjort's second hypothesis. Can. J. Fish. Aquat. Sci. 42: $602-608$

Underwood, A. J., Denley, E. J. (1984). Paradigms, explanations, and generalizations in models for the structure of intertidal communities on rocky shores. In: Strong, D. R., Simberloff, D. S., Abele, L. G., Thistle, A. B. (ed.) Ecological communities: conceptual issues and the evidence. Princeton University Press, Princeton

Vance, R. R. (1978). A mutualistic interaction between a sessile marine clam and its epibionts. Ecology 59: 679-685

Wethey, D. S. (1985). Catastrophe, extinction, and species diversity: a rocky intertidal example. Ecology 66: 445-456

Young, C. M., Chia, F.-S. (1984). Microhabitat-associated variability in survival and growth of subtidal solitary ascidians during the first 21 days after settlement. Mar. Biol. $81: 61-68$ 